\title{
Establishment and characterization of two cell lines from bluefin trevally Caranx melampygus
}

\author{
Zhengshan Zhao, Yuanan Lu* \\ Retrovirology Research Laboratory, Pacific Biomedical Research Center, University of Hawaii at Manoa, Leahi Hospital, \\ 3675 Kilauea Avenue, Honolulu, Hawaii 96816, USA
}

\begin{abstract}
Bluefin trevally Caranx melampygus Cuvier is a popular game fish and highly valued sea food with potential importance for aquaculture. To help establish this marine animal as an important aquacultural species in Hawaii and the Pacific and develop in vitro cell culture systems for long-term management and control of potential viral diseases 2 cell lines were established from body muscle (bluefin trevally muscles, BTMS) and fins (bluefin trevally fins, BTF). Primary culture of these cells was conducted at $25^{\circ} \mathrm{C}$ using L-15 medium supplemented with $20 \%$ fetal bovine serum and various antibiotics. These cells have been serially subcultured 37 to 41 times since their initiation in June 2002. Growth of the bluefin trevally cells was serum-dependent at the time of the experiments and their plating efficiencies ranged from 11 to $28.2 \%$. Comparative analysis showed that these bluefin trevally cells grew equally well in the media L-15 (Leibovitz medium), RPMI 1640, M199 and MEM (minimum essential medium), which are commonly used for cell cultures derived from aquatic animals and mammalian species. Examination of the early passage cells stored at $-196^{\circ} \mathrm{C}$ revealed a large percent (nearly $98 \%$ ) of cell viability following a 6 mo storage in liquid nitrogen. Karyotyping analysis indicated that these bluefin trevally derived cell lines remained diploid with a chromosome count of 48 at passage 7 and 12 . These 2 cell lines shared a same pattern of viral susceptibility and they were sensitive to infectious hematopoietic necrosis virus (IHNV), infectious pancreatic necrosis (IPN), spring viremia carp virus (SVCV), viral hemorrhagic septicemia virus (VHSV), and snakehead rhabdovirus (SHRV) but refractory to channel catfish virus (CCV) infection. These newly established cell lines are currently being used to facilitate the diagnosis of viral disease affecting marine fish aquaculture in Hawaii, and will be available for future isolation and study of bluefin trevally fish viruses.
\end{abstract}

KEY WORDS: Cell lines · Caranx melampygus $\cdot$ Bluefin trevally $\cdot$ Omilu

\section{INTRODUCTION}

Bluefin trevally Caranx melampygus Cuvier, which is also known as 'Omilu' in Hawaii, is a member of the jack or Carangidae family (Meyer et al. 2001). There are a total of over 200 jack species and blue jack C. melampygus is the most common one in Hawaii and the Pacific (Meyer et al. 2001). As a coastal and oceanic species, bluefin trevally is found widely throughout the Indopan-Pacific and is associated with reefs (Smith-Vaniz 1995). The rich environment of the coral reef supports a complex food web and provides rich hunting grounds for bluefin trevally species (Anonymous 2004). The juveniles appear seasonally in large numbers in shallow, sandy inner reef flats in shore waters while the adults range widely throughout deeper lagoon and outer reef waters, and they usually enter channels and shallow reef areas (Lieske \& Myers 1994, Smith-Vaniz 1995). Blue jack and other predators also play a key role in the community, contributing to the balance of life in the reef habitat (Anonymous 2004). Adult bluefin trevally usually occur singly or in small schools, except at the south tip of Peleliu in Palau (Republic of Palau), where an enormous aggregation of over 1000 individuals was documented (Smith-Vaniz 1995). Omilu, like other jacks, are large, active reef-associated predators. Trevally larvae are pelagic opportunistic feeders, feeding on zooplankton (Kim et al. 2001), while adult trevally prey mostly on reef 
fish and also crustaceans (Potts 1980, Holland et al. 1996). This warm-water marine finfish can grow to $1 \mathrm{~m}$ in body length (Lieske \& Myers 1994).

Bluefin trevally is an important source of food and also a prize catch for recreational fisherman. Because of its relatively high market value, it is currently being developed for aquaculture and stock enhancement in the Pacific, particularly in Hawaii (Leber 1994). Recent studies have shown that bluefin trevally reaches sexual maturity between 30 and $40 \mathrm{~cm}$ standard length (SL) or at about 2 yr of age (Sudekum et al. 1991, Moriwake et al. 2001). This species is a multiple and serial spawner that appears to spawn more than once a year. Most importantly, bluefin trevally adapt well to captive conditions and are able to breed in confined conditions (Moriwake et al. 2001). This means that they can provide a reliable supply of eggs and larvae, enhancing the success of blue jack aquaculture.

Despite the popularity of blue jack as a game fish and highly valued food with potential importance for aquaculture (Sudekum et al. 1991, Holland et al. 1996), little is known about their sensitivity/resistance to infectious agents, particularly the infections caused by pathogenic viruses. Viruses have been frequently reported from fish, crustacean species and other marine animals; some viruses are highly lethal and are responsible for many significant losses of farmed marine animals (Wolf et al. 1960, Amend et al. 1969, Wolf \& Darlington 1971, Plumb 1978, Lightner \& Redmann 1981, Sano et al. 1981, Boonyaratpalin et al. 1992, Chantanachookin et al. 1993, Chen 1995, Loh et al. 1997, Lu et al. 1997, Osterhaus et al. 1997). The lack of cell lines derived from bluefin trevally currently hinders the study and diagnosis of viral diseases of this fish. Successful development of blue jack farming in Hawaii and also worldwide is dependent partly on the establishment of permissive cell lines from this marine species for the isolation, cultivation, study, and control of pathogenic viruses.

In the present paper, we describe methods for the establishment of 2 cell lines from trevally and provide a characterization of their optimum growth, karyological typing and susceptibility to several fish viruses. These newly characterized trevally cell lines (bluefin trevally muscle [BTMS] and bluefin trevally fins [BTF], derived from omilu body muscle and fins, respectively) represent the first report of an in vitro cell culture system from this species. These cell lines may provide an important biological tool for future detection and diagnosis of trevally viruses.

\section{MATERIALS AND METHODS}

Primary cultures. One apparently healthy bluefin trevally with a body weight of $148 \mathrm{~g}$ and a body length of $18 \mathrm{~cm}$ was used in this study. To initiate primary cell culture, 1 to $2 \mathrm{~g}$ of the following tissues were aseptically collected from the fish into antibiotic-incubation medium (AIM): heart, spleen, muscle (under mouth), snout, kidney and swim bladder. Tissue samples were incubated at room temperature $\left(25 \pm 2^{\circ} \mathrm{C}\right)$ for $2 \mathrm{~h}$ in AIM consisting of $1 \times$ Leibovitz medium (L-15), $1000 \mu \mathrm{g}$ $\mathrm{ml}^{-1}$ streptomycin, $1000 \mathrm{U} \mathrm{ml}^{-1}$ penicillin, $25 \mu \mathrm{g} \mathrm{ml}^{-1}$ amphotericin B and $250 \mu \mathrm{g} \mathrm{ml}^{-1}$ gentamicin. Following 2 additional washes with AIM (15 min per wash), tissue specimens were minced with sterile instruments, and 20 to 30 tissue fragments ( 1 to $2 \mathrm{~mm}^{3}$ ) were explanted in each $25 \mathrm{~cm}^{2}$ Primaria-brand tissue culture flask (Falcon Primaria, Fisher Scientific).

Primary cell cultures were initially maintained in L-15 medium supplemented with $20 \%$ heat-inactivated fetal bovine serum (FBS) (Hyclone Laboratories) with various antibiotics (200 U penicillin, $200 \mu \mathrm{g}$ streptomycin, $50 \mu \mathrm{g}$ gentamicin, and $5 \mu \mathrm{g}$ amphotericin $\mathrm{B} \mathrm{ml}^{-1}$ ), according to previously described methods ( $\mathrm{Lu}$ et al. 1999), and incubated at $25^{\circ} \mathrm{C}$. When cells grew and became confluent, cells were subcultivated at a ratio of $1: 2-3$ every 5 to $7 \mathrm{~d}$ using a $0.25 \%$ trypsinversene solution (Sigma Chemical).

Optimal growth studies. Growth characteristics of the newly established trevally cell lines were evaluated by growing cells in selected media, at different incubation temperatures, and using or excluding FBS. To determine the incubation temperature for optimal cell growth, approximately $4.5 \times 10^{5}$ bluefin trevally cells at the 12th passage were seeded in $25 \mathrm{~cm}^{2}$ tissue culture flasks (Corning Labware). These cultures were grown in L-15 medium containing $10 \%$ FBS and incubated at $15,20,25,30$ and $37^{\circ} \mathrm{C}$. Cells from 2 flasks at each temperature were trypsinized on alternate days for a total of $10 \mathrm{~d}$, and average cell counts were calculated. In the same manner, the effect of differing concentrations of FBS $(0,5,10$ and $20 \%)$ and of different tissue culture media (RPMI 1640, medium 199 [M199], L-15 and minimum essential medium [MEM]) on cell growth was also assessed in duplicate $25 \mathrm{~cm}^{2}$ flasks incubated at $25^{\circ} \mathrm{C}$.

Cell-plating efficiency. The plating efficiency of BTMS and BTF cells was tested at passage 6 and 10 according to the method of Fryer et al. (1981). Cells in the exponential growth phase were harvested and diluted in L-15 medium containing $10 \%$ FBS. Following incubation at $25^{\circ} \mathrm{C}$ for $14 \mathrm{~d}$, the cells were fixed, and stained. The cell colonies were counted and cellplating efficiency was calculated using the method described by Middlebrooks et al. (1981).

Cryopreservation of cells. The stability of bluefin trevally cells in liquid nitrogen storage was examined. Briefly, cells growing logarithmically were harvested and diluted at a cell density of $2 \times 10^{6}$ cells ml ${ }^{-1}$ in L-15 
medium containing $20 \%$ FBS and dimethyl sulfoxide (DMSO) at a final concentration of $10 \%$. Aliquots $(1.0 \mathrm{ml})$ of cell suspension were dispensed into $1.5 \mathrm{ml}$ sterile plastic vials (NUNC), sealed, and processed for storage in liquid nitrogen. Cell viability was assessed at Day 180 by trypan blue exclusion (Wang et al. 2003).

Karyotyping of cells. Chromosome counts were conducted for BTF and BTMS at their 7th and 12th passages, respectively, according to the method described by Earley (1975). One hundred or more chromosome spreads were counted for each cell line using phasecontrast microscopy.

Ribosomal RNA analysis. Total DNA was extracted from $2.5 \times 10^{7}$ BTF cells at passage 18 according to the method described previously (Lu et al. 2000). Two sets of oligonucleotide primers were designed to amplify 16S bluefin trevally mitochondrial DNA: the first fragment (343 bp) using forward (16S-F1) 5'-CTCAAGCCTCGCCTGTTTAC-3' and reverse (16S-R1) 5'-CCC AACCGAAGACATTAGGA-3' primers and the second fragment (312 bp) using forward (16S-F2) 5'-CAA GGGCGCAATAGAAAAAG-3' and reverse (16S-R2) 5'-GAGAAGCCATGAGGCTGAAC-3' primers. The Invitrogen Platinum PCR SuperMix kit (Cat. No. 11306-016) was used for the PCR reaction. The final eluted volume of $50 \mu \mathrm{l}$ reaction mix includes: forward primer $(20 \mu \mathrm{M}) 0.4 \mu \mathrm{l}$, reverse primer $(20 \mu \mathrm{M}) 0.4 \mu \mathrm{l}$, and template $0.3 \mu \mathrm{g}$. PCR cycling conditions were as follows: initial denature at $94^{\circ} \mathrm{C}$ for $5 \mathrm{~min}$; followed by 40 cycles of $94^{\circ} \mathrm{C}$ for $1 / 2$ min (denature), $55^{\circ} \mathrm{C}$ for $1 / 2 \min$ (annealing) and $72^{\circ} \mathrm{C}$ for $1 / 2$ min (extension); and final extension at $72^{\circ} \mathrm{C}$ for $7 \mathrm{~min}$ and then hold at $4^{\circ} \mathrm{C}$.

The PCR products were subjected to $2 \%$ agarose gel electrophoresis and purified using a gel extraction kit (Qiagen). The purified PCR fragments were directly sequenced in both directions using an automated sequencer (373A, Applied Biosystems). The amplified sequences were identified by the Editseq and Seqman programs of the DNAstar package and then blastered in GenBank.

Viral susceptibility. Newly established bluefin trevally cell lines were tested for their susceptibility to 4 fish rhabdoviruses: snakehead rhabdovirus (SHRV), infectious hematopoietic necrosis virus (IHNV), spring viremia carp virus (SVCV), and viral hemorrhagic septicemia virus (VHSV); 1 fish herpesvirus, channel catfish virus (CCV) and 1 birnavirus, infectious pancreatic necrosis virus (IPNV) (Table 1), according to the methods described previously (Lu et al. 2003). Virus stocks were prepared and viral yields were determined in chinook salmon embryo cells (CHSE-214) for IHNV, IPNV and VHSV, while SHRV and SVCV were prepared in epithelioma papulosum cyprini (EPC) cells and CCV was titered in brown bullhead (BB). BTF and BTMS cells $\left(2.5 \times 10^{5}\right)$ were incubated at $25^{\circ} \mathrm{C}$ until a subconfluent monolayer ( 80 to $90 \%$ ) was achieved in $25 \mathrm{~cm}^{2}$ tissue culture flasks and then inoculated with a 3.5 to $4.5 \times 10^{4} 50 \%$ tissue culture infectious dose $\left(\mathrm{TCID}_{50}\right)$ of each virus stock (multiplicity of infection $=\sim 0.2$ ). Following virus adsorption for $1 \mathrm{~h}$ at the temperature optimal for each virus, unadsorbed virus was removed by washing cell monolayers twice with L-15 medium containing no FBS. Then $5 \mathrm{ml}$ of L-15 medium containing $5 \%$ FBS was added to each flask and infected cultures were transferred to an incubation temperature optimal for viral infection (SHRV and CCV at $25^{\circ} \mathrm{C}$, IHNV and VHSV at $15^{\circ} \mathrm{C}$, IPNV and SVCV at $20^{\circ} \mathrm{C}$ ). Infected cultures were monitored daily for virus-specific cytopathic effects (CPE). Cultures were frozen at $-80^{\circ} \mathrm{C}$ when more than $80 \%$ of cells showed CPE or at Day 7 if no CPE developed. Viral susceptibility of trevally cells was evaluated by the appearance of viral-specific $\mathrm{CPE}$ and the production of infectious virus as determined by measuring TCID 50 (Reed \& Muench 1938).

\section{RESULTS}

\section{Cell morphology}

Out of 6 selected tissues/organs from 1 bluefin trevally, we were able to establish 2 cell lines, BTMS and BTF, derived from muscle and fin tissues, respectively. These 2 cell lines were serially passed in vitro more than 37 times since their initiation in June 2002. Morphologically, fin-derived BTF appeared epithelial/ fibroblast-like while BTMS derived from muscle was epithelial in appearance (Fig. 1).

Table 1. Summary of 6 viruses used in this study

\begin{tabular}{|lccc|}
\hline Virus & Abbreviation & Family & Source \\
\hline Channel catfish virus & CCV & Herpesviridae & $\begin{array}{c}\text { Wolf \& Darlington } \\
\text { (1971) }\end{array}$ \\
$\begin{array}{c}\text { Infectious hemato- } \\
\text { poietic necrosis virus }\end{array}$ & IHNV & Rhabdoviridae & $\begin{array}{c}\text { Amend et. al. } \\
\text { (1969) }\end{array}$ \\
$\begin{array}{l}\text { Infectious pancreatic } \\
\text { necrosis virus }\end{array}$ & IPNV & Birnaviridae & Wolf et. al (1960) \\
$\begin{array}{l}\text { Snakehead rhabdo- } \\
\text { virus }\end{array}$ & SHRV & Rhabdoviridae & Kasornchandra et al. \\
$\begin{array}{l}\text { Spring viremia of } \\
\text { carp virus }\end{array}$ & SVCV & Rhabdoviridae & Fijan et al. (1971) \\
$\begin{array}{l}\text { Viral hemorrhagic } \\
\text { septicemia virus }\end{array}$ & VHSV & Rhabdoviridae & Brunson et al. (1989) \\
\hline
\end{tabular}



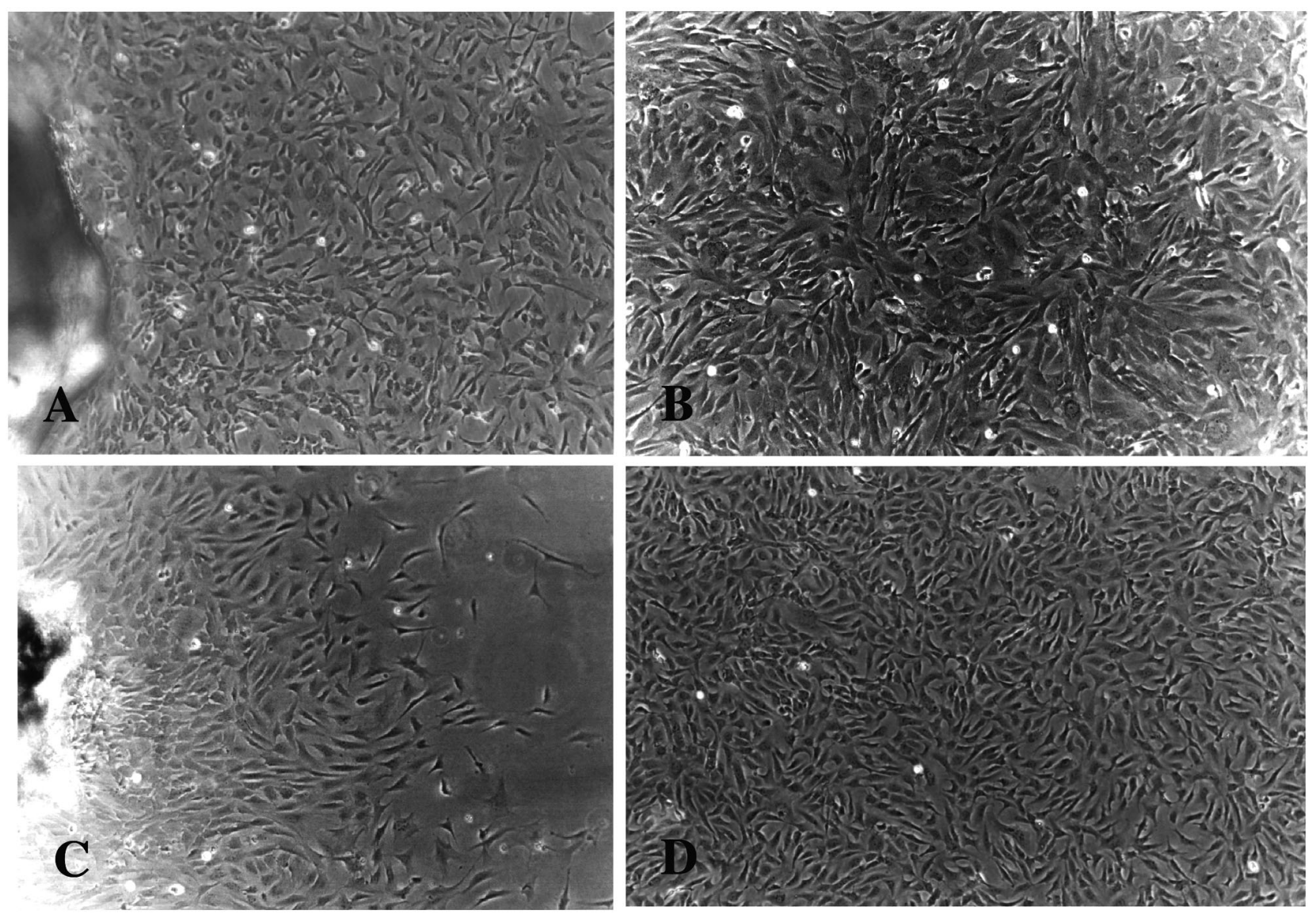

Fig. 1. Caranx melampygus. Photomicrographs of bluefin trevally cells derived from $(\mathrm{A}, \mathrm{B})$ fins and $(\mathrm{C}, \mathrm{B})$ muscle tissue. (A) and (C) show primary cultures on Day 7 following seeding tissue explants; (B) and (D) show subcultured cells at passage 12. Magnification $=120 \times$

\section{Growth characteristics}

Initial growth of cells derived from fins was observed on Day 2 following the explanting of minced tissue fragments, and a cell monolayer had formed by Day 10. In comparison, initial growth of muscle-derived cells was slower and no growing cells were observed until Day 4 of incubation. However, following 10 passages, BTMS cells exhibited growth kinetics similar to those of BTF. Both cell lines were then subcultured every 5 to $7 \mathrm{~d}$ at a $1: 2-3$ split ratio.

The newly established bluefin trevally cell lines grew well at a temperature range of 20 to $30^{\circ} \mathrm{C}$ with the optimal temperature falling between 25 and $30^{\circ} \mathrm{C}$. As shown in Fig. 2, both BTMS and BTF cells grew very rapidly when incubated at 25 to $30^{\circ} \mathrm{C}$, with cell doubling times (dt) of approximately $50 \mathrm{~h}$. Although bluefin trevally cells were able to attach and spread in the cell culture flask at $20^{\circ} \mathrm{C}$, the cells showed slower growth kinetics $(\mathrm{dt}>8 \mathrm{~d})$. No cell spreading and growth were observed when cells were incubated at either 15 or $37^{\circ} \mathrm{C}$. Since bluefin trevally is considered to be a tropical marine fish species, it is not surprising that these cell cultures propagate efficiently at 25 to $30^{\circ} \mathrm{C}$.

Our experimental data also indicated that both BTMS and BTF cells grew well in L-15 supplemented with FBS, but not in L-15 alone (Fig. 2). BTMS cells grew more rapidly in L-15 containing 20\% FBS (dt < $47 \mathrm{~h}$ ) as compared to a slower growth with $10 \%$ FBS (dt $=$ approximately $98 \mathrm{~h}$ ), and an even slower growth rate in $5 \%$ FBS. Since the growth of BTMS and BTF were serum-dependent, this suggested that these cells were not yet transformed. Also, in the current passage the plating efficiencies of these cell lines were low $(<25 \%)$, which further supported the untransformed status of the newly established omilu cell lines. Comparison of 4 different cell culture media commonly used for animal cells cultures showed that all these media supported the growth of BTMS cells equally well. However, the BTF cell line did not grow well in medium 199 as compared to the other 3 media. This may reflect the selective tendency of different cell types with respect to their nutrients. 

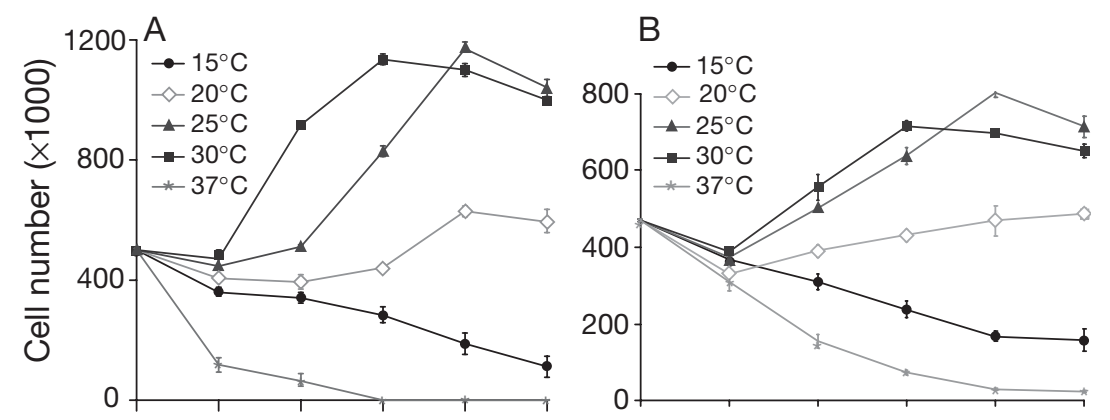

passages of BTMS and BTF indicated that these 2 bluefin-derived cell lines shared a similar pattern of chromosomal distribution (Fig. 3). Chromosomal counts from 100 or more randomly selected cells ranged from 36 to 98 , but the majority of the counted cells had between 46 and 52 chromosomes (78 to $85 \%$ of all spreads) with a distinct peak of 48 for the 2 cell lines (Fig. 3). Our
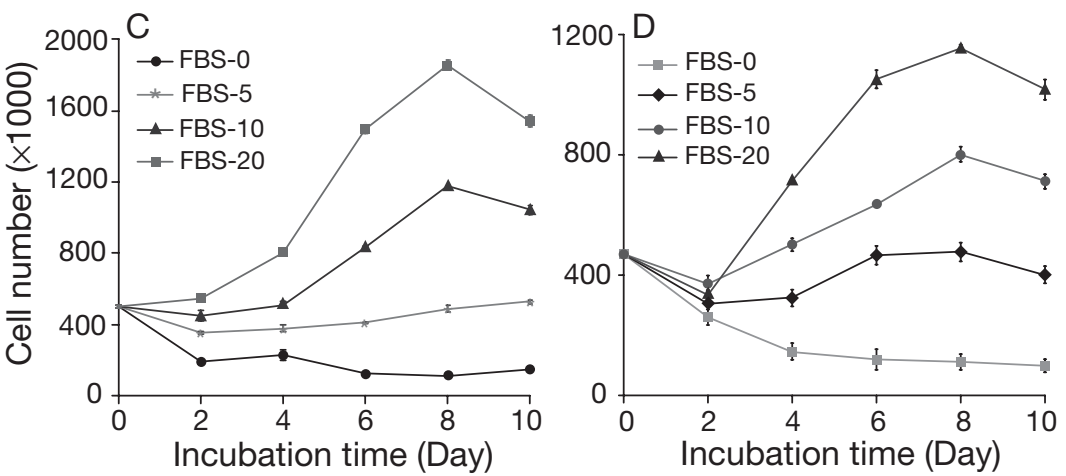
finding that these 2 cell lines had the same peak range of chromosomes during their early passage in vitro suggests that the diploid chromosome number of bluefin trevally may be $48(2 \mathrm{n}=48)$ and that these cell lines were diploid during the cell passages in the present study.

\section{Sequence analysis of $16 \mathrm{~S}$ ribosomal RNA (rRNA)}

Fig. 2. Caranx melampygus. In vitro growth curves $( \pm \mathrm{SE})$ of the 2 established bluefin trevally cell lines. $(\mathrm{A}, \mathrm{C})$ Bluefin trevally fins $(\mathrm{BTF})$ and $(\mathrm{B}, \mathrm{D})$ bluefin trevally muscle (BTMS) cells were propagated at $(A, B)$ different temperatures and $(C, D)$ selected concentrations of fetal bovine serum (FBS)

\section{Plating efficiency}

Plating efficiency for the 2 bluefin cell lines ranged from 11 (BTMS) to $28.2 \%$ (BTF) tested at passages 6 and 10, respectively. These low and broad ranges of plating efficiency may suggest that the cells were in heterogeneous stages but not fully adapted to in vitro growth conditions during these early passages.

\section{Cryopreservation}

Assessment of the viability of BTMS and BTF cells stored in liquid nitrogen demonstrated that all cells were stable and were able to survive low temperature storage. Over $97.8 \%$ of the cell population remained viable for a period of $180 \mathrm{~d}$ storage at $-196^{\circ} \mathrm{C}$. All viable cells attached and grew well following seeding at $25^{\circ} \mathrm{C}$. No apparent change in cellular morphology was observed following the storage.

\section{Chromosomal analysis}

Although bluefin trevally is the most abundant and ubiquitous carangid in Hawaii and throughout much of the tropical Pacific, little is known about the diploid chromosome number of this fish. Karyotyping of early
Amplification of the DNA extracted from BTF cells using the 2 pairs of PCR primers designed from the 16S mitochondrial DNA of bluefin trevally revealed the expected PCR products of 343 and $312 \mathrm{bp}$, respectively (Fig. 4). Comparative sequence analysis indicated that these newly identified sequences were nearly identical $(98.7 \pm 1.0 \%)$ to the respective mitochondrial DNAs of bluefin trevally (GenBank accession no. AP004445). In addition, these 2 sets of PCR primer pairs were also employed to amplify the DNA isolated from the BTF cells at passage 5 and 43, respectively, and the resulting sequences were identically matched with the respective sequences detected at the 18th passage (data not shown). These data indicated that the BTF and BTMS are truly derived from bluefin trevally Caranx melampygus.

\section{Viral susceptibility}

The sensitivity of the 2 fish cell lines to 6 viruses was determined. Both BTMS and BTF appeared to share a similar spectrum of virus susceptibility: sensitive to SVCV, IHNV, IPNV, SHRV and VHSV, but refractory to $\mathrm{CCV}$ (Table 2). Viral infection resulted in extensive CPE in these 2 cell lines by Day 2 (Fig. 5), and SVCV infection induced visible CPE within $48 \mathrm{~h}$ post-infection (p.i.). It was of interest to note that although infec- 

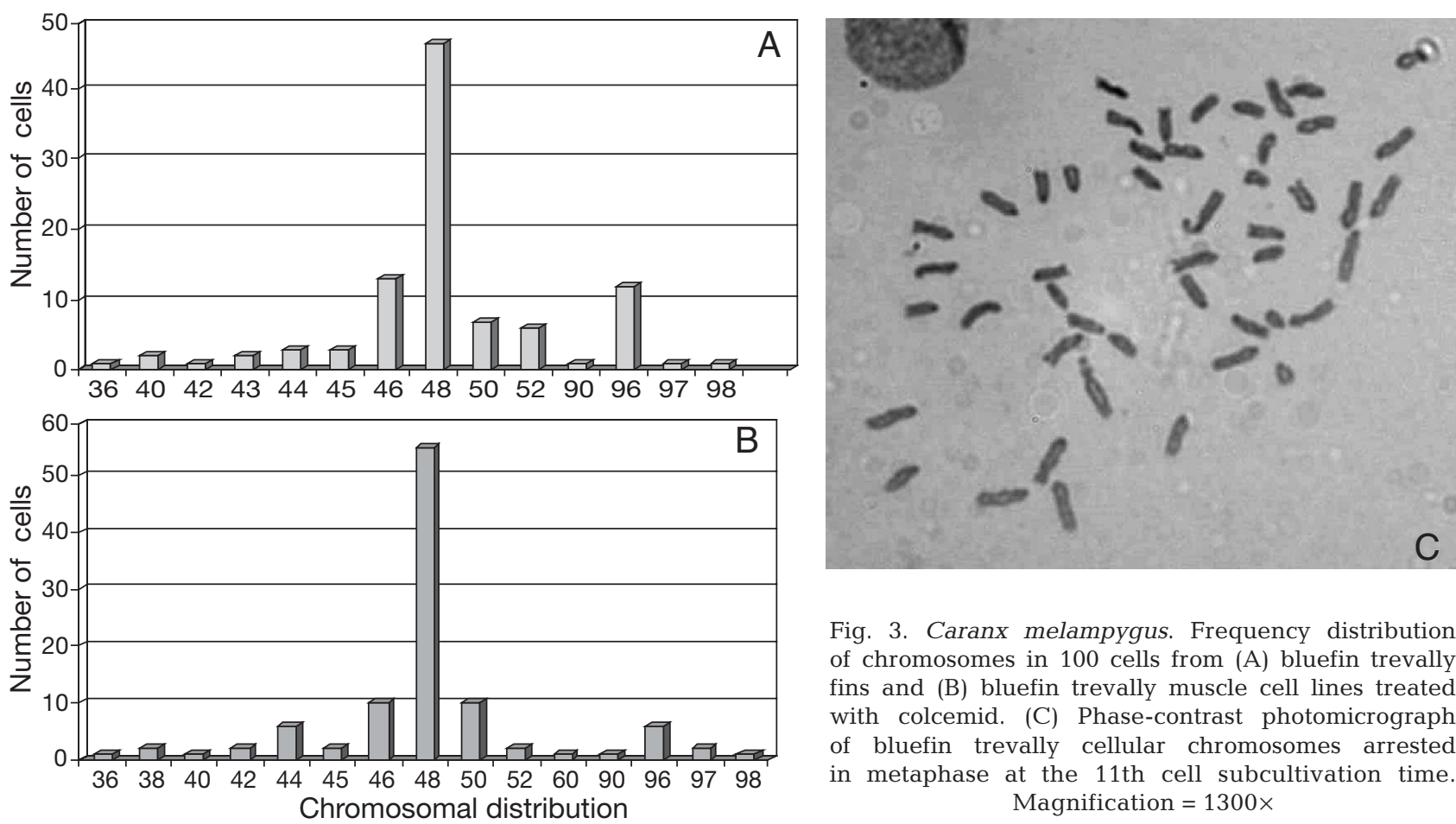

Fig. 3. Caranx melampygus. Frequency distribution of chromosomes in 100 cells from (A) bluefin trevally fins and (B) bluefin trevally muscle cell lines treated with colcemid. (C) Phase-contrast photomicrograph of bluefin trevally cellular chromosomes arrested in metaphase at the 11th cell subcultivation time. Magnification $=1300 \times$

tion of BTMS and BTF cells with VHSV resulted in apparent CPE within $3 \mathrm{~d}$, a very low yield of infectious virus was produced by these cells (10 ${ }^{3.3-3.6}$ $\mathrm{TCID}_{50} \mathrm{ml}^{-1}$ ). In contrast, comparable virus yields to control cell lines were obtained in new bluefin trevally cell lines for SVCV $\left(10^{8.0-8.5} \mathrm{TCID}_{50} \mathrm{ml}^{-1}\right)$ and IPNV $\left(10^{6.0-6.5} \mathrm{TCID}_{50} \mathrm{ml}^{-1}\right)$. Based on viral-induced CPE and viral production, the BTMS cell line appeared to be more susceptible to viral infections than BTF. The wide range of viral susceptibility suggests that the 2 newly established bluefin trevally cell lines can serve as sensitive biological indicators for future isolation and study of marine and freshwater fish viruses.

\section{DISCUSSION}

Animal tissue culture was initiated at the beginning of the 20th century as a simple technique to study the behavior of animal cells (Harrison 1907, Freshney 2000).

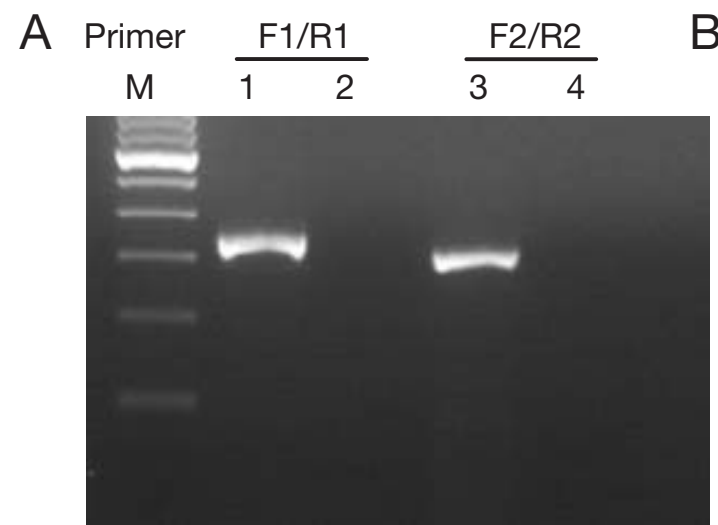

B $16 \mathrm{~S} \mathrm{F1/R1}$

CTCAAGCCTC GCCTGTTTAC CAAAAACATC GCCTCTTGCA AAACCAAAGA ATAAGAGGTC CCGCCTGCCC GGTGACTATA TGTTTAACGG CCGCGGTATT TTGACCGTGC GAAGGTAGCG TAATCACTTG TCTTTTAAAT GGAGACCTGT ATGAATGGCA TAACGAGGGC TTAACTGTCT CCTCTTTCCA GTCAATGAAA TTGATCTCCC CGTGCAGAAG CGGGGATAAA CACATAAGAC GAGAAGACCC TATGGAGCTT TAGACACCAA GACAGATCAT GTTAAATACC CCTTGACAAA GGCCCGAACT TAATGACCCC CTGTCCTAAT GTCTTCGGTT GGG

$16 \mathrm{~S}$ F2/R2

CAAGGGCGCA ATAGAAAAA TACCGTAAgG GAAAgCTGAA AGAGAGATGA AACAGACCAG TAAAGCCATA AAAAGCAGAG ATTACTCCTC GTACCTTTTG CATCATGATT TAGCCAGCAC ATTCAAGCAA AGAGAACTTT AGTTTGAAAT CCCGAAACTG TGTGAGCTAC TCCAAGACAG CCTATTTATA GGGCAAACCC GTCTCTGTGG CAAAAGAGTG GGAAGAGCTT CGAGTAGGGG TGACAGACCT ATCGAACTCA GTTATAGCTG GTTGCCCGGG AATTGGATAA AAGTTCAGCC TCATGGCTTC TC

Fig. 4. Caranx melampygus. (A) PCR amplification of 343 and 312 bp sequences of the bluefin trevally genome using 2 pairs of oligonucleotide primers (F1/R1 and F2/R2) designed from the conserved portions of the 16S mitochondrial DNA. DNA (100 ng) isolated from bluefin trevally fin (BTF) cells was amplified and then subjected to $2.0 \%$ gel electrophoresis. Lanes 1 and 3: BTFDNA; lanes 2 and 4: negative control; M ( molecular marker): 100 bp DNA ladder (showing the range 100 to 800 bp. (B) Nucleotide sequences of the 343 and $312 \mathrm{bp}$ fragments amplified by PCR using the respective primers. Underlined portions represent positions of the PCR primers 
Table 2. Comparison of the 2 newly established bluefin trevally cell lines for the propagation of selected fish viruses. (For virus definitions, see Table 1.) CPE: cytopathic effect; $\mathrm{TCID}_{50}: 50 \%$ tissue culture infectious dose; BTMS: bluefin trevally muscle; BTF: bluefin trevally fins; BB: brown bullhead; CHSE: chinook salmon embryo cells; EPC: epithelioma papulosum cyprini; -: did not occur

\begin{tabular}{|llccc|}
\hline Virus & Cell line & $\begin{array}{c}\text { CPE occurrence } \\
\text { (Day) }\end{array}$ & \multicolumn{2}{c|}{$\begin{array}{c}\text { TCID }_{50} \text { (units } \mathrm{ml}^{-1} \text {, log titer) } \\
\text { Day 0 }\end{array}$} \\
\hline Day 7
\end{tabular}

This technique has been well defined today and widely used in many diagnostic and research laboratories. A large number of cell lines have been established from a variety of marine species, including aquacultured fish (Wolf \& Mann 1980, Fijan et al. 1983, Lannan et al. 1984, Chen \& Kou 1988, Lu et al. 1990, Fryer \& Lannan 1994, Wang et al. 2003, Zhao et al. 2003) marine mammals (Kadoi et al. 1992, Lu et al. 1998, 2001, Kumar et al. 2001), endangered marine species (Moore et al. 1997, Lu et al. 1999), and marine crustaceans (Tapay et al. 1995, Neuman et al. 2000). However, for Caranx species, there has only been one report of the establishment of an in vitro cell culture derived from omaka Caranx mate fish larvae (Lee \& Loh 1975). There is no documentation of an in vitro cell line established from bluefin trevally. Furthermore, little is known about the chromosomal counts of this marine animal or the degree to which it is affected by viral infection. Since bluefin trevally is becoming an important aquacultural species in Hawaii and the Pacific, there
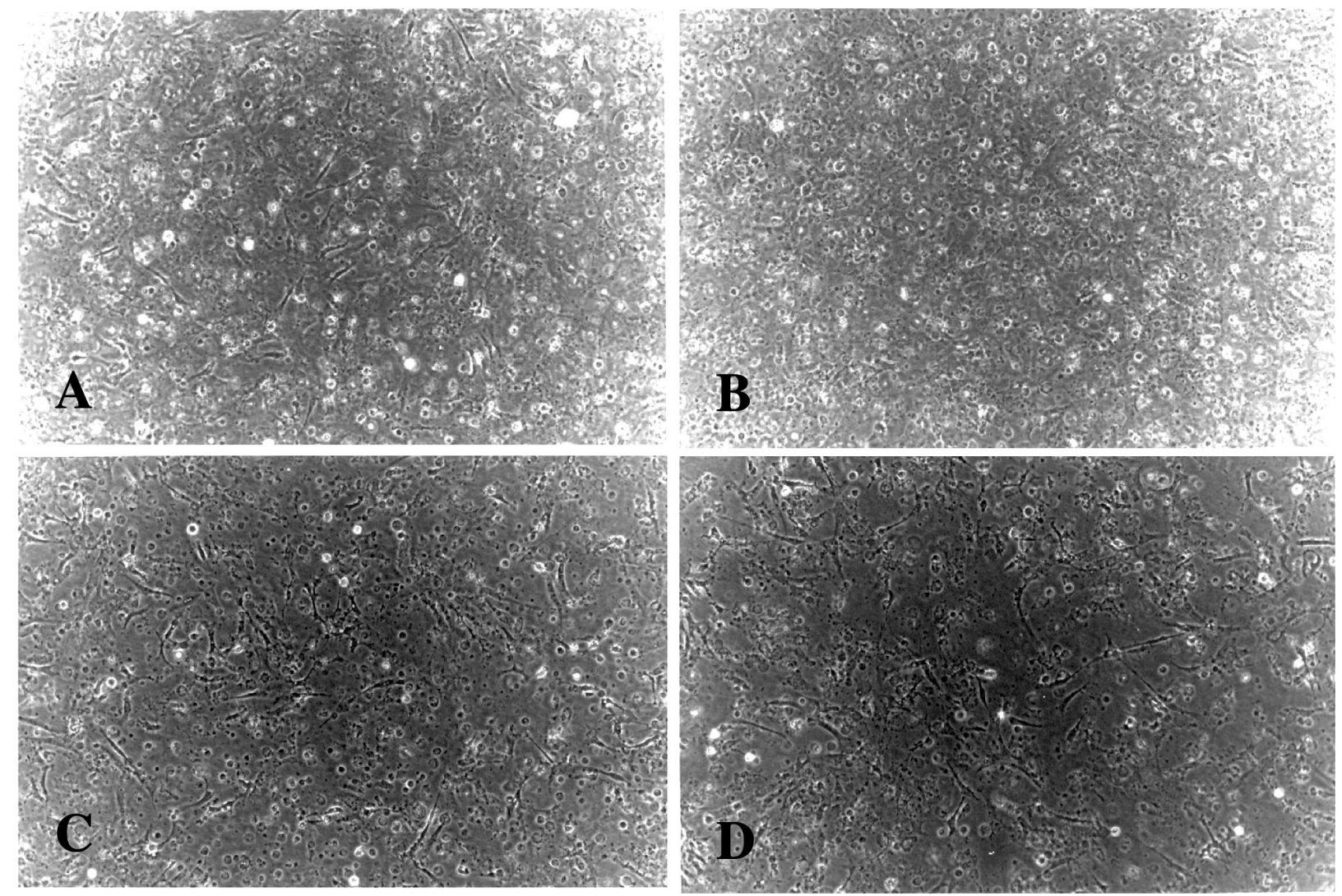

Fig. 5. Caranx melampygus. Microphotographs of viral-induced cytopathic effects in bluefin trevally. Bluefin trevally fin (BTF) cells infected with (A) IHNV and (C) VHSV and bluefin trevally muscle (BTMS) cells infected with (B) IHNV and (D) VHSV at Day 2 post-infection. Magnification $=110 \times$. See Table 1 for definitions of virus abbreviations 
is an urgent need to gain a biological understanding of this fish, and to develop a biological tool for the detection and diagnosis of infectious viruses which affect it. To that end, the aim of this study was to establish and characterize cell lines from bluefin trevally.

Although our initial attempt was to establish primary cell cultures from multiple tissues and organs including the liver, kidney, spleen, swim bladder, muscle, fin and heart, we were only able to establish 2 cell lines from the muscle (BTMS) and fin (BTF). Initially, cell growth was observed in the kidney, spleen, heart and swim bladder, but subculture was not successful. This was partially due to the limited amount of tissue specimen available for primary culture from the donor fish and also probably due to non-optimized in vitro cell culture conditions. Both the BTF and BTMS cells were serially subcultivated up to 37-41 passages in vitro and grew well at 25 to $30^{\circ} \mathrm{C}$. Both cell lines can be easily maintained since they are stable either frozen in liquid $\mathrm{N}_{2}$ storage or in cell culture flasks.

Among several major applications of established cell lines in virology is the use of permissive cell cultures to detect and diagnose viral infections, to isolate, propagate and assay infectious viruses, and to prepare and clone attenuated virus strains for antiviral vaccination. Cell lines established from a variety of marine species have been successfully used for the isolation, identification and detection of many kinds of marine viruses, including highly pathogenic viral isolates, which provides baseline information for the development of a long-term strategy for viral disease prevention and control (Wolf 1988, Hetrick \& Hedrick 1993, Leong \& Fryer 1993, Lu et al. 1995, Frerichs et al. 1996, Winton 1997, Watson et al. 1998, Alonso et al. 1999, Crane et al. 2000, Danneving et al. 2000, Lopez-Doriga et al. 2001, Chen et al. 2004, Denis-Mize et al. 2004). Although there are currently no reports of natural viral infection in Caranx species, this does not necessarily mean that this species is free of viral infection. In fact, little viral surveillance of this fish has been done because of the lack of a cell culture system which can be used as a sensitive biological tool to monitor infection. A viral challenge test of the established BTMS and BTF cells indicated that these 2 new cell lines are sensitive to all of the viruses tested except for CCV, suggesting a relatively wide range of viral susceptibility. These findings may indicate that the BTMS and BTF cells could be potentially used to isolate and study pathogenic viruses affecting bluefin trevally and other fish species.

Cell cultures have been widely used in many other applications, including the determination of host genetics and chromosomal characteristics. The diploid chromosome number for bluefin trevally is not known. The present study on 2 established cell lines from this fish revealed that BTMS and BTF shared a similar pattern of chromosomal distribution and had the same peak count of 48 (46 to 56 chromosones). Since karyotyping analysis was performed during the early passages of these cell lines, this suggest that both cell lines may have a diploid number of chromosomes of $2 n=48$. In the future the modal chromosomal number of this species and the host origin of established bluefin trevally cell lines should be ascertained by employing G-banding or other karyotyping techniques.

In order to further identify the origin of the established cell lines, DNAs isolated from the cells during their early subculture (Passage 18) were amplified by PCR using 2 sets of oligonucleotide primer pairs designed from different portions of the conserved mitochondrial genome of bluefin trevally (accession number AP004445). Comparative analysis of the amplicon sequences showed that they are nearly identical $(98.7 \%)$ to the respective portions of the reported bluefin trevally $16 \mathrm{~S}$ mitochondrial DNA, indicating that BTF and BTMS are truly derived from bluefin trevally Caranx melampygus.

Acknowledgements. We thank Ms. D. Montgomery-Brock for her assistance with the collection of donor fish for this study and Dr. P. C. Loh for his comments on the manuscript. This research was supported in part by funding from the Center for Tropic and Subtropic Aquaculture, Oceanic Institute, Honolulu, and the Wildlife Preservation Trust International, Philadelphia, Pennsylvania (99-00-115).

\section{LITERATURE CITED}

Alonso M, Rodriguez S, Perez-Prieto SI (1999) Viral coinfection in salmonids: infectious pancreatic necrosis virus interferes with infectious hematopoietic necrosis virus. Arch Virol 144(4):657-673

Amend D, Yasutake FWT, Mead RW (1969) A hematopoietic virus disease of rainbow trout and sockeye salon. Trans Am Fish Soc 98:796-804

Anonymous (2004) Hunters of the reef. http://waquarium. otted.hawaii.edu/MLP/root/pdf

Boonyaratpalin S, Supamattaya K, Kasornchandra J, Direkbusaracom S, Aekpanithanpong U, Chantanachooklin C (1992) Non-occluded baculo-like virus, the causative agent of yellow head disease in the black tiger shrimp (Penaeus monodon). Gyobyo Kenkyu 28(3):103-109

Brunson RK, True K, Yancey J (1989) VHS virus isolated at Makah National Fisheries Hatchery. American Fisheries Society. Fish Health Newsl 17:3

Chantanachookin C, Boonyaratpalin S, Kasornchandra J, Direkbusarakon S, Ekpanithanpong U, Supamataya K, Sriurairatana S, Flegel TW (1993) Histology and ultrastructure reveal a new granulosis-like virus in Penaeus monodon affected by yellow-head virus. Dis Aquat Org 17:145-157

Chen SN (1995) Current status of shrimp aquaculture in Taiwan. In: Browdy CL, Hopkins JS (eds) Swimming through troubled water. Proceedings of the special session of shrimp farming. Aquaculture'95. World Aquaculture Society, Baton Rouge, LA, p 29-34

Chen SL, Ren GC, Sha ZX, Shi CY (2004) Establishment of a continuous embryonic cell line from Japanese flounder 
Paralichthys olivaceus for virus isolation. Dis Aquat Org 60:241-246

Chen SN, Kou GH (1988) Establishment, characterization and application of 14 cell lines from warm-water fish. In: Kuroda Y, Kurstak E, Maramorosch K (eds) Invertebrate and fish tissue culture. Japan Science Society, Tokyo, p 218-227

Crane MS, Hardy-Smith P, Williams LM, Hyatt AD and 5 others (2000) First isolation of an aquatic birnavirus from farmed and wild fish species in Australia. Dis Aquat Org 43(1):1-14

Dannevig BH, Nilsen R, Modahl I, Jankowska M, Taksdal T, Press CM (2000) Isolation in cell culture of nodavirus from farmed Atlantic halibut Hippoglossus hippoglossus in Norway. Dis Aquat Org 43(3):183-189

Denis-Mize K, Fout GS, Dahling DR, Francy DS (2004) Detection of human enteric viruses in stream water with RT-PCR and cell culture. J Water Health 2(1):37-47

Earley EM (1975) Chromosome preparations from monolayer cell cultures. TCA (Tissue Cult Assoc) Man 1:31-35

Fijan N, Petrinec Z, Sulimanovic D, Zwillenberg L (1971) Isolation of the viral causative agent from the acute form of infectious dropsy of carp. Vet Arh 41:125-138

Fijan, N, Sulimsnovic D, Bearzotti M (1983) Some properties of the epithelioma papulosum cyprini (EPC) cell line from carp, Cyprinus carpio. Ann Virol 134:207-220

Frerichs GN, Rodger HD, Peric Z (1996) Cell culture isolation of piscine neuropathy nodavirus from juvenile sea bass, Dicentrarchus labrax. J Gen Virol 77:2067-2071

Freshney RI (2000) Culture of animal cells, a manual of basic technique. Wiley-Liss, New York

Fryer JL, Lannan CN (1994) Three decades of fish cell culture: a current list of cell lines derived from fishes. Dis Aquat Org 16:87-94

Fryer JL, McCain BB, Leong JC (1981) A cell line derived from rainbow trout (Salmo gairdneri) hepatoma. Fish Pathol 15:193-200

Harrison, RG (1907) Observation on the living developing nerve fiber. Proc Soc Exp Biol Med 4:140-143

Hetrick FM, Hedrick JP (1993) New viruses described in finfish from 1988-1992. Annu Rev Fish Dis 3:187-207

Holland KN, Lowe CG, Wetherbee BM (1996) Movements and dispersal patterns of blue trevally (Caranx melampygus) in a fisheries conservation zone. Fish Res 25:279-292

Kadoi K, Mochizuki A, Ikeda T, Kamata H, Yukawa M, Inoue Y (1992) Susceptibility of a line of dolphin kidney cell culture to several herpesviruses. J Basic Microbiol 32: $227-232$

Kasornchandra J, Lannan CN, Rohovec JS, Fryer JL (1991) Characterization of a rhabdovirus isolated from the snakehead fish (Ophicephalus striatus). In: Freyer JL (ed) Second international symposium on viruses of lower vertebrates. Oregon State University Press, Corvalis, OR, p175-182

Kim BG, Divakaran S, Brown CL, Ostrowski AC (2001) Comparative digestive enzyme ontogeny in two marine larval fishes: Pacific threadfin (Polydactylus sexfilis) and bluefin trevally (Caranx melampygus). Fish Physiol Biochem 24: 225-241

Kumar GS, Singh ISB, Philip R (2001) Development of a cell culture system from the ovarian tissue of African catfish (Clarias gariepinus). Aquaculture 194:51-62

Lannan CN, Winton JR, Fryer JL (1984) Fish cell lines: establishment and characterization of nine cell lines from salmonids. In Vitro 20:671-676

Leber KM (1994). Prioritization of marine fishes for stock enhancement in Hawaii. The Oceanic Institute, Honolulu, $\mathrm{HI}$
Lee MH, Loh PC (1975) Some properties of an established fish cell line from the marine fish, Caranx mate (Omaka). Proc Soc Exp Biol Med 150:40-48

Leong JC, Fryer JL (1993) Viral vaccines and aquaculture. Annu Rev Fish Dis 3:225-250

Lieske E, Myers R (1994) Collins pocket guide. Coral reef fishes. Indo-Pacific \& Caribbean including the Red Sea. Harper Collins Publishers, London

Lightner DV, Redman RM (1981) A baculovirus-caused disease of the penaeid shrimp, Penaeus monodon. J Invertebr Pathol 38:299-302

Loh PC, Tapay LM, Lu Y, Nadala ECB (1997) Viral pathogens of the penaeid shrimp. Adv Vir Res 48:263-312

Lopez-Doriga MV, Smail DA, Smith RJ, Domenech A, Castric J, Smith PD, Ellis AE (2001) Isolation of salmon pancreas disease virus (SPDV) in cell culture and its ability to protect against infection by the 'wild-type' agent. Fish Shellfish Immunol 11(6):505-522

Lu Y, Lannan CN, Rohovec JS, Fryer JL (1990) Fish cell lines establishment and characterization of three new cell lines from grass carp (Ctenopharyngodon idella). In Vitro Cell Dev Biol 26:275-279

Lu Y, Tapay LM, Loh PC, Brock JA, Gose RB (1995) Development of a quantal assay in primary shrimp cell culture for yellow head baculovirus (YBV) of penaeid shrimp. J Virol Methods 52(1-2):231-236

Lu Y, Tapay LM, Loh PC, Brock JA, Gose RB (1997) Chinese baculo-like virus (CBV), a highly pathogenic viral agent found in cultured penaeid shrimp. Aquac Int 5:277-282

Lu Y, Aguirre AA, Braun RC, Loh PC (1998) Establishment of monk seal cell lines. In Vitro Cell Dev Biol-Animal 34: 367-369

Lu Y, Nerurkar VR, Aguirre AA, Work TM, Balazs GH, Yanagihara R (1999) Establishment and characterization of 13 cell lines from a green sea turtle (Chelonia mydas) with fibropapillomas. In Vitro Cell Dev Biol 35(7):389-393

Lu Y, Wang Y, Yu Q, Aguirre AA, Balazs GH, Nerurkar VR, Yanagihara R (2000) Detection of herpesviral sequences in tissues of green turtles with fibropapilloma using polymerase chain reaction. Arch Virol 145:1885-1893

Lu Y, Aguirre AA, Hamm C, Wang Y, Yu Q, Loh PC, Yanagihara R (2001) Establishment, cryopreservation, and growth of 11 cell lines prepared from a juvenile Hawaiian monk seal, Monachus schauinslandi. In Vitro Cell Dev Biol 22:115-124

Lu Y, Aguirre AA, Wang Y, Loh PC, Yanagihara R (2003) Viral susceptibility of newly established cell lines from the Hawaiian monk seal. Dis Aquat Org 57:183-191

Meyer CG, Holland KN, Wetherbee BM, Lowe CG (2001) Diet, resource partitioning and gear vulnerability of Hawaiian jacks captured in fishing tournaments. Fish Res 53:105-113

Middlebrooks BL, Stout DL, Ellender RD (1981) Fish cell lines: two new cell lines derived from explants of trunk musculature of Cynoscion arenarius. In Vitro Cell Dev Biol 17: $427-430$

Miya M, Takeshima $\mathrm{H}$, Endo $\mathrm{H}$, Ishiguro NB and 7 others (2003) Major patterns of higher teleostean phylogenies: a new perspective based on 100 complete mitochondrial DNA sequences. Mol Phylogenet Evol 26(1):121-138

Moore MK, Work TM, Balazs GH, Docherty DE (1997) Preparation, cryopreservation, and growth of cells prepared from the green turtle (Chelonia mydas). Methods Cell Sci 19:161-168

Moriwake AM, Moriwake VN, Ostrowski AC, Lee CS (2001) Natural spawning of the bluefin trevally Caranx melampygus in capitivity. Aquaculture 203:159-164 
Neuman T, Kaiser HE, Rath FW (2000) A permanent cell line of the crayfish Orconectes limosus as a potential model in comparative oncology. In Vivo 14:691-698

Osterhaus A, Groen J, Niesters H, van de Bildt BW and 6 others (1997) Morbillivirus in monk seal mass mortality. Nature 388:838-839

Plumb JA (1978) Epizootiology of channel catfish virus disease. Mar Fish Rev 40:26-29

Potts GW (1980) The predatory behavior of Caranx melampygus in the channel environment of Aldabra Atoll. J Zool Sci (Lond) 192:323-350

Reed LJ, Muench H (1938) A simple method of estimating fifty per cent endpoints. Am J Hyg 27:493-497

Sano T, Nishimura T, Oguma K, Momoyama K, Takeno N (1981) Baculovirus infection of cultured Kuruma shrimp, Penaeus japonicus in Japan. Fish Pathol 15:185-191

Smith-Vaniz WF (1995) Carangidae. Jureles, pámpanos, cojinúas, zapateros, cocineros, casabes, macarelas, chicharros, jorobados, medregales, pez pilota. In: Fischer W, Krupp F, Schneider W, Sommer C, Carpenter KE, Niem V (eds) Guia FAO para identificación de especies para los fines de la pesca. Pacifico Centro-Oriental, 3 vols. FAO, Rome, p 940-986

Sudekum AE, Parrish JD, Radtke R, Ralston S (1991) Life history and ecology of large jacks in undisturbed shallow, oceanic communities. Fish Bull US 89:493-513

Tapay LM, Lu Y, Brock JA, Nadala ECB, Loh PC (1995) Trans-

Editorial responsibility: Jo-Ann Leong,

Kaneohe, Hawaii, USA formation of primary cultures of lymphoid (Oka) organ from a penaeid shrimp, Penaeus stylirostris with simian virus-40 T-antigen. Proc Exp Biol Med 209:73-78

Wang G, LaPatra S, Zeng L, Zhao Z, Lu Y (2003) Establishment, growth, cryopreservation and species of origin identification of three cell lines from white sturgeon, Acipenser transmontanus. Methods Cell Sci 25:211-220

Watson LR, Groff JM, Hedrick RP (1998) Replication and pathogenesis of white sturgeon iridovirus (WSIV) in experimentally infected white sturgeon Acipenser transmontanus juveniles and sturgeon cell lines. Dis Aquat Org 32:173-184

Winton JR (1997) Immunization with viral antigens: infectious haematopoietic necrosis. Dev Biol Stand 90:211-220

Wolf K (1988) Fish viruses and fish viral diseases. Cornell Press, Ithaca, NY

Wolf K, Darlington RW (1971) Channel catfish virus: a new herpesvirus of ictalurid fish. J Virol 8:532-533

Wolf K, Mann JA (1980) Poikilotherm vertebrate cell lines and viruses: a current listing for fishes. In Vitro 16:168-179

Wolf K, Snieszko SF, Dunbar CE, Pyle E (1960) Virus nature of infectious pancreatic necrosis in trout. Proc Soc Exp Biol Med 104:105-108

Zhao ZS, Montgomery-Brock D, Lee CS, Lu Y (2003) Establishment, characterization and viral susceptibility of 3 new cell lines from snakehead, Channa striatus (Blooch). Meth Cell Sci 2:155-166

Submitted: February 15, 2005; Accepted: October 4, 2005

Proofs received from author(s): January 13, 2006 